\title{
A strain ratio based modification on low-cycle fatigue model for asymmetric loading
}

\author{
Junhong Zhang ${ }^{1}$, weidong $\mathrm{li}^{2}$, Jiewei $\mathrm{Lin}^{1}$, yongbo qiu ${ }^{2}$, tianyi zhou ${ }^{2}$, and peng $\mathrm{wu}^{2}$ \\ ${ }^{1}$ Tianjin University \\ tianjin university
}

May 5, 2020

\begin{abstract}
Mean stress based correction on low cycle fatigue (LCF) model shows limit in asymmetric loading cases in both accuracy and applicability. After studying the affecting mechanism of strain ratio on fatigue life of LCF, a strain ratio based modification on Manson-Coffin model is proposed considering variation of elastic and plastic strain. Linear correlations between strain ratio and fatigue strength coefficient and between strain ratio and fatigue ductility coefficient are developed and employed in the model correction. Model verification is conducted through three materials: high-pressure tubing steel (HPTS), 2124-T851 aluminum alloy and epoxy resin, under different strain ratios. Comparing with current widely used LCF models, including Goodman, Walker, Morrow, Kwofie and SWT models, the proposed model modification shows better life prediction accuracy and higher potential in replication from symmetric to asymmetric loading cases as well as the availability among different materials. It is also found the strain ratio based correction is able to consider the damage of ratcheting strain that the mean stress based models cannot.
\end{abstract}

\section{Hosted file}

main document.docx available at https://authorea.com/users/298344/articles/427902-a-strainratio-based-modification-on-low-cycle-fatigue-model-for-asymmetric-loading

\section{Hosted file}

Figure.docx available at https://authorea.com/users/298344/articles/427902-a-strain-ratiobased-modification-on-low-cycle-fatigue-model-for-asymmetric-loading

\section{Hosted file}

Table.docx available at https://authorea.com/users/298344/articles/427902-a-strain-ratiobased-modification-on-low-cycle-fatigue-model-for-asymmetric-loading 